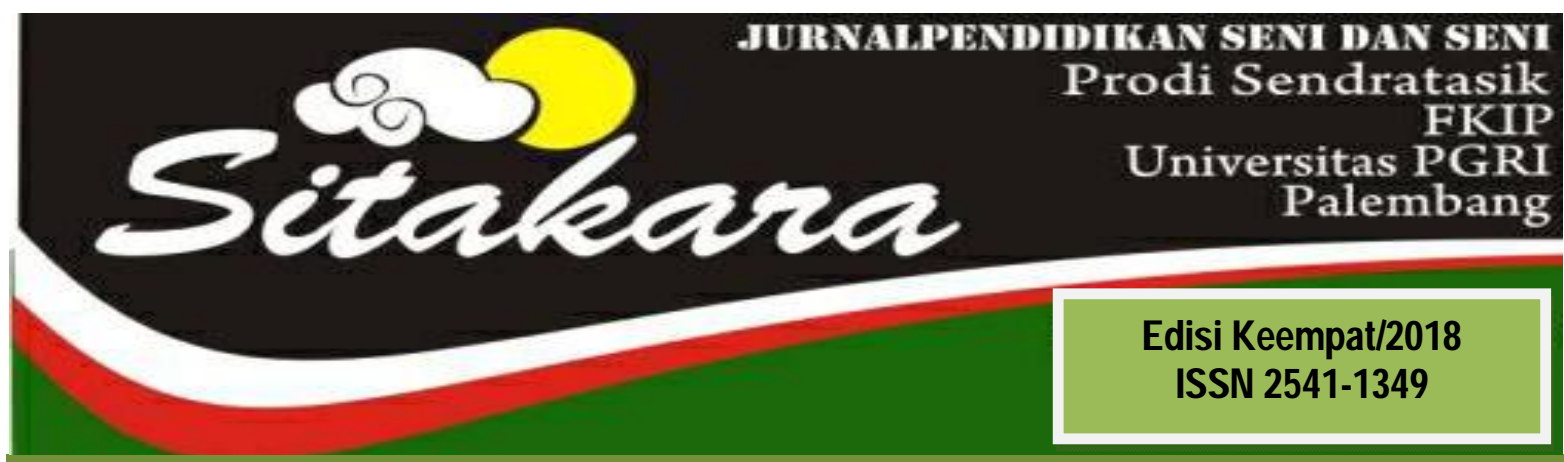

Objektifitas Imajinatif Dalam Pertunjukan Teater

Mohammad A rfani

Makna Estetis Dalam Simbol Tatto

Novdaly Fillamenta

Desain A tas (Air D esign) D alam Dimensi Estetik Pertunjukan Karya Tari

Efita Elvandari

Pengaruh M etode D emonstrasi D alam Pembelajaran Tari Burung Bermain

Pada Kegiatan Ekstrakurikuler D i SM P N egeri 36 Palembang

Ria Moulina A driamul

Gerak: Perjalanan D ari M otif Ke Komposisi Tari

Rully Rochayati

Sastra Lisan Dalam Kesenian Saluang D endang Sumatera Barat

Nofroza Yelli

Rangsang A udio Sebagai M otivasi Pada Penciptaan Karya

Tari Tunggu Tubang Dalam Pembelajaran Koreografi di Universitas

PG RI Palembang

Treny Hera

M otif Bungo Pacik Pada Tenunan Songket Palembang

Mainur

Konsep Kreatifitas Wallas D alam Proses Penciptaan Tari Tepak Keraton

Nurdin

A nalisis Bentuk Gerak Tari Turak Di Sanggar Studio Lingga

Kota Lubuklinggau

Sisca Fitriani

Bentuk Figur Tokoh Wayang Kulit Palembang

Robert Budi Laksana 


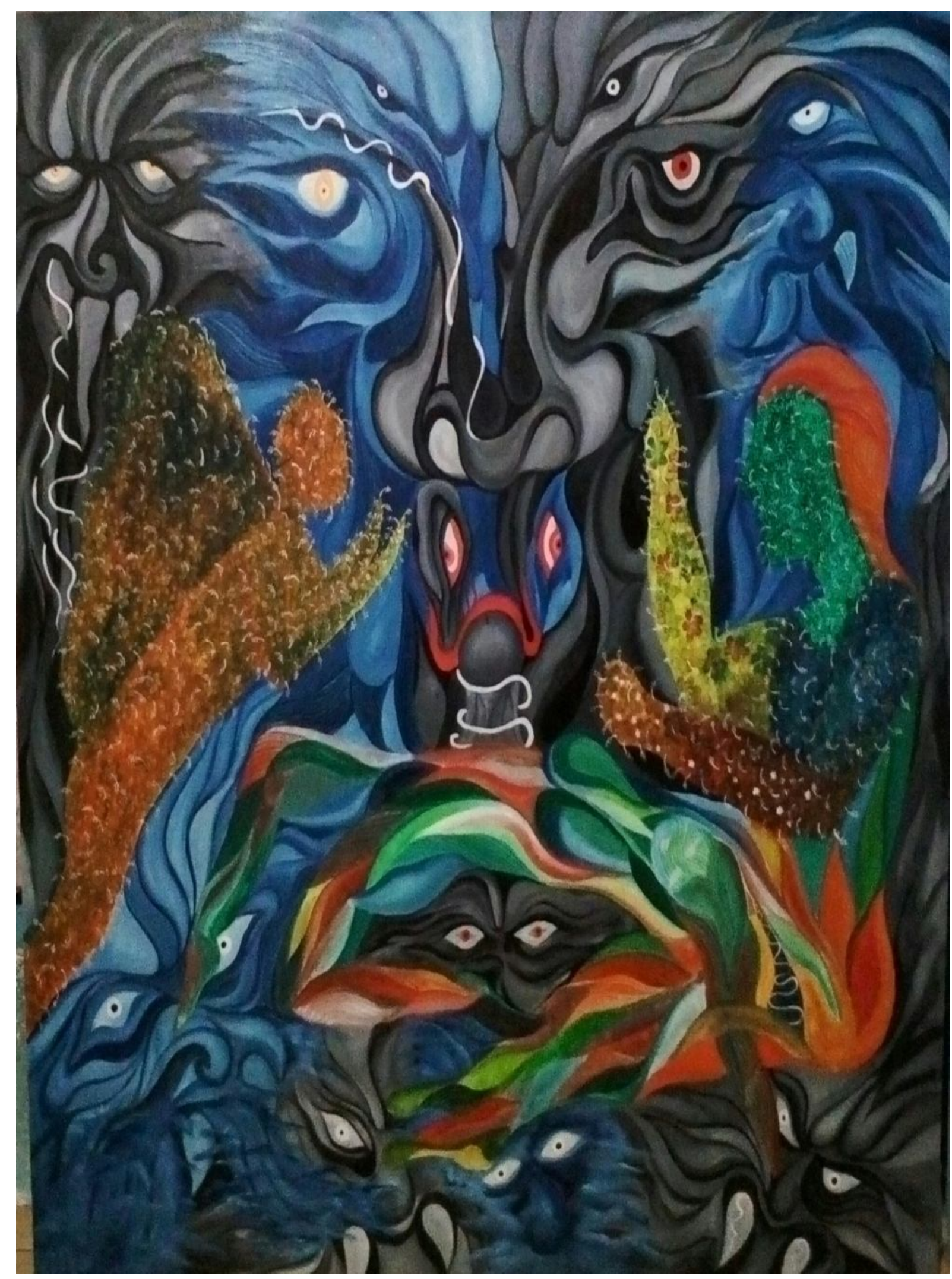




\section{SITAKARA}

\section{JURNAL PENDIDIKAN SENI DAN SENI BUDAYA}

Edisi 4, Februari 2018

\section{DEWAN REDAKSI}

1. PenanggungJawab

2. KetuaDewan Redaksi

3. WakilDewanRedaksi

4. Sekretaris

5. PenyuntingPelaksana

6. Penyunting Ahli

7. Setting
:

: Dra. Andinasari, M.M., M.Pd.

: RullyRochayati, M.Sn

: Nofroza Yelli, M.Sn

: Treny Hera, S.Pd., M.Sn

: 1. Efita Elvandari, M.Sn

2. Arfani, S.Pd., M.Sn

: 1. Prof. Dr. Triyono Bramantyo, P.Hd (ISI Yogyakarta)

2. Dr. DessyWardiah, M.Pd (UPGRI)

3. Dr. Slamet, M.Hum (ISI Surakarta)

4. Yayan Hariyansyah, M.Sn (UIGM)

: 1. Mainur, S.Pd.,M.Sn

2. I Komang Kerta Yana, S.Si

\section{AlamatRedaksi}

Program StudiPendidikanSendratasik JurusanPendidikanKesenian FKIP Universitas PGRI Palembang Jl. A. YaniLorongGotongRoyong 9/10 Ulu Palembang Telp. 0711-510043 Fax. 0711-514782 E-mail: jurnalsitakarasendratasik@yahoo.com 


\section{DAFTAR ISI}

Objektifitas Imajinatif D alam Pertunjukan Teater

M ohammad A rfani

Makna Estetis D alam Simbol Tatto

Novdaly Fillamenta

D esain A tas (Air D esign) D alam D imensi Estetik Pertunjukan Karya Tari

Efita Elvandari

Pengaruh M etode D emonstrasi D alam Pembelajaran Tari Burung Bermain 25 Pada Kegiatan Ekstrakurikuler Di SM P N egeri 36 Palembang

Ria M oulina Adriamul

G erak: Perjalanan D ari M otif Ke Komposisi Tari

Rully Rochayati

SastraL isanD al amK esenianSaluangD endang Sumatera Barat

N ofroza Yelli

Rangsang Audio Sebagai M otivasi Pada Penciptaan Karya

Tari Tunggu Tubang Dalam Pembelajaran Koreografi di Universitas

PG RI Palembang

Treny Hera

Motif Bungo Pacik Pada Tenunan Songket Palembang

Mainur

Konsep K reatifitas Wallas D alam Proses Penciptaan Tari Tepak Keraton N urdin

Analisis Bentuk G erak Tari Turak Di Sanggar Studio Lingga

Kota Lubuklinggau

Sisca Fitriani

BentukFigurT okohWayangKulit Palembang 


\title{
OBJEKTIFITAS IMAJINATIF DALAM PERTUNJUKAN TEATER
}

\author{
Oleh: \\ Mohammad Arfani*)
}

\begin{abstract}
ABSTRAK
Gagasan bentuk teater adalah hasil dari dunia khayalan yang dimulai dengan deskripsi tentang kemanusiaan. Sehingga pada pemahaman lain teater sebagai komunikasi objektivitas dan imajiner menjadi media dalam menyampaikan pesan dalam pertunjukan teater.
\end{abstract}

\section{Kata kunci: objektivitas imajinatif dalam pertunjukan teater}

\section{A. PENDAHULUAN}

Drama sering dihubungkan dengan teater. Sebenarnya teater memiliki makna yang lebih luas. Kata 'teater' barasal dari kata Yunani kuno yaitu Theatron yang kurang lebih artinya sebagai tempat pertunjukan. Secara tersirat menurut Padmodarmaya (1988:21) teater adalah suatu kegiatan manusia secara sadar menggunakan tubuhnya sebagai alat atau media utama untuk menyatakan rasa dan karsanya, mewujud dalam suatu karya (seni). Dalam menyatakan rasa dan karsanya itu, alat atau media utama tiada ditunjang oleh unsur gerak, unsur suara bunyi, dan unsur rupa.

Kemudian istilah drama sebagai bentuk pengartian yang lebih khusus, Harymawan (1986:1) mengatakan bahwa drama juga berasal dari kata Yunani yaitu Draomai dan kata Romawi yaitu Dramas yang berarti berbuat, berlaku, bertindak, bereaksi, dan sebagainya. Drama berarti perbuatan dan tindakan. Semi (1987:156) menyimpulkan bahwa drama adalah cerita atau perilaku manusia yang dipentaskan. Hal ini juga kembali didukung dengan pendapat Harymawan
(1986:2) bahwa drama adalah cerita konflik manusia dalam bentuk dialog yang diproyeksikan pada pentas yang menggunakan percakapan dan action dihadapan penonton (audience).Adapun tujuan seni pertunjukan khususnya teater adalah menyodorkan segala bentuk informasi, data faktual serta analisis kritis, sehingga tersedia sumber materi walau belum dalam mencapai bentuk yang komperhensif, tetapi setidaknya dapat dipakai sebagai titik tolak dalam pembelajaran teks drama lebih lanjut.

Setiap tindakan pasti ada resiko, baik dalam segi subjektif dan objektif. Begitu juga dalam pembuatan buku ini yang banyak sekali kekurangannya. Sehingga penulis menyadari masih banyak pertanyaan yang belum terjawabkan dalam perkembangan teks dan drama itu sendiri.

\section{DRAMATURGI}

Dramaturgi merupakan kaidah konvensional yang membahas masalah hukumhukum drama tentang apapun yang berhubungan didalamnya. Pada awalnya seorang teoritis 
literatur Amerika dan filsuf ditahun 1945, K.D. Burke (1897-1993) memperkenalkan konsep dramatik sebagai metode untuk memahami fungsi sosial dari bahasa dan drama sebagai pentas simbolik kata dan kehidupan sosial. Tujuan Dramatisme adalah memberikan penjelasan logis untuk memahami motif tindakan manusia, atau kenapa manusia melakukan apa yang mereka lakukan. Dramatis memperlihatkan bahasa sebagai model tindakan simbolik ketimbang model pengetahuan (Burke, 1978), pandangan Burke adalah bahwa hidup bukan seperti drama, tapi hidup itu sendiri adalah drama. Teori dramatis Burke kemudian diperdalam dan disempurnakan kajiannya oleh seorang sosiolog interaksionis Erving Goffman (1922-1982) dalam bukunya yang terkenal sebagai sumbangan terbesar bagi teori ilmu sosial The Presentation of Self In Everyday Life yang membahas masalah fenomena interaksi simbolik yang mendalam pada kajian dramaturgi.

Dramaturgi adalah ajaran tentang masalah hukum, dan kovensi atau persetujuan drama. Istilah Dramaturgi kental dengan pengaruh drama atau teater atau pertunjukan fiksi diatas panggung dimana seorang aktor memainkan karakter manusia-manusia yang lain sehingga penonton dapat memperoleh gambaran kehidupan dari tokoh tersebut dan mampu mengikuti alur cerita dari drama yang disajikan. Meski benar, dramaturgi juga digunakan dalam istilah teater namun tema dan karakteristiknya berbeda dengan dramaturgi didalam pembahasannya.
Perlu diingat, dramatugi mempelajari konteks dari perilaku manusia dalam mencapai tujuannya dan bukan untuk mempelajari hasil dari perilakunya tersebut. Dramaturgi memahami bahwa dalam interaksi antar manusia ada perilaku yang disetujui yang dapat mengantarkan kepada tujuan akhir dari maksud interaksi sosial tersebut. Bermain peran merupakan salah satu alat yang dapat mengacu kepada tercapainya kesepakatan tersebut. Bukti nyata bahwa terjadi permainan peran dalam kehidupan manusia dapat dilihat pada masyarakat kita sendiri. Manusia menciptakan sebuah mekanisme tersendiri, dimana dengan permainan peran tersebut ia bisa tampil sebagai sosok-sosok tertentu. Teori dramaturgi menjelaskan bahwa identitas manusia adalah tidak stabil dan merupakan setiap identitas tersebut merupakan bagian kejiwaan psikologi yang mandiri. Identitas manusia bisa saja berubah-ubah tergantung dari interaksi dengan orang lain. Disinilah dramaturgi masuk, bagaimana kita menguasai interaksi secara objektifitas.

\section{B. METODE PENELITIAN}

Secara umum meode yang dipakai yaitu menggunakan metode deskriptif kualitatif, yaitu metode yang serelatif mungkin menjelaskan serta mendeskripsikan, menganalisis, sekaligus menafsirkan struktur yang terdapat dalam teks drama.

Semi (1990:24) menyatakan bahwa penelitian deskriptif artinya data yang terurai 
dalam bentuk kata-kata atau gambar-gambar, bukan dalam bentuk angka-angka dengan pendekatan kualitatif tang bersifat deskriptif berpandangan bahwa semua hal yang berupa sistem bahasa dan tanda tidak ada yang patut diremehkan, semuanya penting dan mempunyai pengaruh pada kaitannya dengan yang lain. Sebagai suatu pendekatan dengan menggunakan metode deskriptif kualitatif, pendekatan dinilai dengan permasalahan yang diangkat terutama dalam melihat sisi objektifitas didalam bentuk pertunjukan teater.

\section{PEMBAHASAN}

Sebelumnya, alasan saya memberikan pada judul tulisan sebagai objektifitas imajinatif karena banyak sekali (karena sering saya temui) mempermasalahkan apresiasi yang bolehlah dikatakan mana yang lebih baik dalam menilai suatu pertunjukan teater. Hingga 'tukang' teater perlu untuk menafsirkan bentuk pertunjukan yang sebenarnya. Tanpa harus memaksa, mari kita kembali pada bangunan teater tersebut pada bentuk semula.

Konsep awal dalam suatu pertunjukan teater adalah perwujudan segala bentuk aksi manusia dan ekspresinya kepanggung, dalam bentuk apapun serta dari sudut pandang manapun. Segala bentuk tematik tentang manusia itu sendiri sangat banyak macam ragamnya, setiap manusia antar individu, kelompok, menjadi suatu masyarakat mempunyai tujuan dan masalahnya. Dari satu bentuk sudut pandang yang dilihat oleh seniman teater yang kemudian diwujudkan menjadi pementasan. Realita yang ada membangun ide kreatifitas dalam bentuk apapun. Perlu dingat kembali, Realitas teater adalah realitas ambang. Ambang adalah suatu tempat atau benda yang memberi peluang kepada kita untuk melihat arah dari sudut manapun.

Manusia sebagai objek merupakan sumber tematik dari berbagai sisi kehidupan, karena manusia itu sendiri melakukan aktivitas dan tujuan atas dasar keinginannya dan segala hal yang menjadi tragedi manusia itu sendiri, yang kemudian seniman teater mendeskripsikan dalan bentuk teks drama hingga membuatnya dalam bangunan berupa pentas panggung. Adalah manusia itu sendiri yang menjadi bentuk kenyataan dalam mengembangkan tema sesungguhnya hingga menjadi kreatifitas yang sesungguhnya dalam berbagai bentuk masalah kemanusiaan, menjadikan kotak yang bernama teater ini berkembang seiring maju pesatnya kemanusiaan itu sendiri dengan menonjolkan nilai kemanusiaan melalui setiap perjalanan dengan mengarahkan kita kepada berbagai bentuk permasalahan dan nilai-nilai kemanusiaan atas segala bentuk naratif dan apapun bentuk inspirasi didalamnya.

Sebagai contoh saat menonton salah satu karya Samuel Beckett Malam dan Mimpinya, kita disuguhkan hanya suara-suara, penataan efek lighting dan durasi yang hanya sekilas. Atau karya William Shakespare Romeo and Juliet yang berhamburan kalimat-kalimat puitis. Dua contoh 
karya tersebut menunjukkan kutub teater yang berbeda tetapi masing-masing menimbulkan efek apresiasi yang dinamis dari banyak sudut pandang.

Hal yang paling penting dalam sebuah karya teater adalah kepekaan terhadap berbagai kejadian yang ada. Alam dan manusia sebagai sumber infiltrasi atas suatu objek teater. Seorang teaterawan sebagai kreator merenungkan dan berfikir atas sumber ide yang ada, kemudian mewujudkannya ke pentas. Gagasan bentuk pementasan teater adalah hasil dari dunia imajiner teaterawan yang berawal dari deskripsi humanitas. Sehingga pada pemahaman lain terhadap teater sebagai komunikasi atas realitas dan imajinernya menjadi medium dalam menyampaikan pesan yang berupa nilai. Karena penyajian pementasan tanpa nilai bukanlah teater.

Tidaklah penting memandang suatu pentas teater berdasarkan bentuk isme yang ada, karena teater adalah kemerdekaan kreator dan apresiator dalam berekspresi dan menilai; yang perlu digaris bawahi adalah nilai kualitas karya teater dilihat dari kejujuran teaterawan itu sendiri dan interpretasi apresiator (penonton) dari berbagai ruang dan banyak 'pintu' intelektual terhadap karya teater yang telah disaksikan secara utuh.

Palembang, 14 Desember 2017

*)Penulis adalah dosen bahasadan teater yang tingal di Palembang.

\section{DAFTAR PUSTAKA}

Anwar, Chairul, 2005, Drama Bentuk-Gaya dan Aliran,Yogyakarta: Elkaphi

Harymawan, RMA, 1986. Dramaturgi, Bandung: Rosdakarya

KM, Saini, 1996. Peristiwa Teater, Bandung: Penerbit ITB

Luxemburg, Jan Van, dkk, 1992, Pengantar IImu Sastra,Jakarta: Gramedia

Semi, M, Atar, 1987, Anatomi Sastra, Padang:Angkasa Raya

Sumardjo, Jakob, 1993, Ihktisar Sejarah Teater Barat, Bandung: Penerbit Angkasa

WS, Hasanuddin, 1986, Drama Karya Dalam Dua Dimensi, Bandung: Penerbit Angkasa 


\section{KETENTUAN PENULISAN ARTIKEL JURNAL SITAKARA}

1. Naskah berbahasa Indonesia bertemakan Seni Budaya yang meliputi hasil penelitian pengajaran seni budaya, cabang seni, dan kebudayaan.

2. Naskah harus asli dan belum pernah dimuat dalam media lain. Naskah dapat berupa hasil penelitian perorangan atau kelompok. Naskah ditulis dengan cara-cara yang sesuai dengan ketentuan penulisan artikel ilmiah menggunakan bahasa Indonesia yang baku, berupa ketikan, beserta soft line dalam CD-RW atau dengan mengirimkan email pada redaksi Jurnal Sitakara dengan alamat email: jurnalsitakarasendratasik@yahoo.com, spasi 1,5 jenis huruf Arrial Narrow ukuran 12, dengan panjang naskah antara 8-15 halaman pada kertas A4.

3. Artikel hasil penelitian memuat:

JUDUL

NAMA PENULIS

ABSTRAK

\section{A. PENDAHULUAN}

B. METODE PENELITIAN

C. HASIL DAN PEMBAHASAN

D. SIMPULAN

4. Artikel kajian konseptual memuat JUDUL

NAMA PENULIS

ABSTRAK

PENDAHULUAN

SUB JUDUL

SIMPULAN

DAFTAR PUSTAKA

\section{: XXX (HURUF KAPITAL)}

: (disertai jabatan dan institusi)

: (Bahasa Indonesia yang memuat 100- 150 kata diikuti kata kunci, dengan jenis huruf Arrial Narrow dan ukuran huruf 11 serta dicetak tebal).

: (Memuat latar belakang masalah, tinjauan pustaka Secara ringkas, masalah dan tujuan penelitian).

: (Berisi simpulan)

: XXX (HURUF KAPITAL)

: (disertai jabatan dan institusi)

: (Bahasa Indonesia yang memuat 100- 150 kata diikuti kata kunci, dengan jenis huruf Arrial Narrow dan ukuran huruf 11 serta dicetak miring)

: (Memuat latar belakang masalah, tinjauan pustaka secara ringkas, masalah penelitian dan tujuan penelitian)

: Sesuai dengan kebutuhan (tanpa numbering)

: (Berisi simpulan dan saran)

: (Berisi pustaka yang dirujuk dalam uraian naskah) 
5. Referensi sumber dalam teks artikel ditulis dengan menggunakan side note, contoh: (Jalalluddin, 1991:79); (Taufik, 2005;350); (Hamid dan Madjid, 2011:43). Sementara penulisan daftar pustaka disusun dengan ketentuan. Nama Pengarang. Tahun Terbit. Judul (dicetak miring). Kota Terbit: Nama Penerbit. Contoh: Koentjaraningrat. 2010. Manusia dan Kebudayaan Di Indonesia. Jakarta: Djambatan.

Daftar pustaka hanya memuat pustaka/sumber yang dirujuk dalam uraian dan disusun menurut abjad, tanpa nomor urut.

6. Naskah yang dimuat akan disunting kembali oleh redaksi tanpa mengubah isinya.

7. Naskah yang ditolak (tidak bisa dimuat) akan dikirim kembali ke penulis dengan pemberitahuan tertulis dari redaksi atau alamat email.

8. Penulis yang naskahnya dimuat akan mendapatkan 1 (satu) majalah nomor yang bersangkutan.

9. Contact Person: Treny (085357344704) dan Mainur (081373165553). 